\title{
Penentuan Klaster Wilayah Kecamatan Berdasarkan Pusat Pelayanan Masyarakat di Wilayah Kepulauan Kabupaten Maluku Tengah Provinsi Maluku
}

\section{Determination of District Area Clusters based on Community Service Centers in the Archipelago Region of Central Maluku Regency Maluku Province}

\author{
llham Marasabessy ${ }^{1}$, Abdullah Marasabessy ${ }^{2}$, Oki Nurul Asma Tualeka $^{3}$, Desmi Insu Tualeka ${ }^{4}$ \\ ${ }^{1}$ Menajemen Sumberdaya Perairan, Fakultas Perikanan, Universitas Muhammadiyah Sorong, Jl. Pendidikan, No. 27, \\ Remu Utara, Malaingkedi, Sorong Utara, Kota Sorong, Papua 98416. \\ 2 PT. Bank Pembangunan Daerah Maluku dan Maluku Utara, Namaelo, Kota Masohi, Kabupaten Maluku Tengah, \\ Maluku 97511. \\ 3 Program Studi Menajemen, Fakultas Ekonomi, Universitas Pattimura. Jl. Ir. M. Putuhena, Poka, Tlk. Ambon, Kota Ambon, \\ Maluku 97233. \\ 4 Program Studi Akuntansi, Fakultas Ekonomi, Universitas Pattimura. Jl. Ir. M. Putuhena, Poka, Tlk. Ambon, Kota Ambon, \\ Maluku 97233. \\ *Penulis Korespondensi: illo.marssy@gmail.com \\ Diterima Agustus 2020/Disetujui Juni 2021
}

\begin{abstract}
ABSTRAK
Konektivitas suatu wilayah menjadi indikator pertumbuhan pusat layanan. Pengabdian kepada masyarakat dilakukan bersama tim dari PT. Bank Pembangunan Daerah Maluku dan Maluku Utara Cabang Maluku Tengah selama tahun 2018. Data dihimpun pada 18 kecamatan di Kabupaten Maluku Tengah melalui Rapid Survey Method potensi wilayah dan dinamika sosial ekonomi masyarakat. Dukungan data BPS Kabupaten Maluku Tengah 2018 menjadi input pelengkap dalam analisis sentralitas. Data diolah secara deskriptif kuantitatif menggunakan analisis skala Guttman/Indeks Sentralitas Marshall dan spatial analisys tools menggunakan perangkat lunak arcmapGIS 10.3.1, untuk memperoleh peta pusat layanan wilayah. Kabupaten Maluku Tengah merupakan wilayah kepulauan, memiliki klasterisasi kecamatan tersebar di Pulau Seram, Ambon, Kepulauan Lease dan Banda. Klaster wilayah kecamatan terbagi pada 4 wilayah dengan tingkat layanan wilayah tertinggi berada di Kecamatan Amahei $(11,14)$ dan terendah di Nusa Laut $(2,50)$. Pertumbuhan ekonomi di kecamatan pada wilayah kepulauan mengalami trand positif, terpusat di Pulau Ambon dan Kepulauan Banda sedangkan indeks sentralitas Kepulauan Lease berada pada kategori menengah ke bawah.
\end{abstract}

Kata kunci: dinamika ekonomi, indeks sentralitas, kepulauan

\begin{abstract}
The connectivity of a region is an indicator the growth of service centers. Community service is carried out with a team from PT. Maluku and North Maluku Regional Development Bank Central Maluku Branch during 2018. Data were collected in 18 districts in Central Maluku Regency through the Rapid Survey Method for regional potential and socio-economic dynamics of the community. Central Maluku Regency BPS data support 2018 is a complementary input in the centrality analysis. The data were processed using quantitative descriptive analysis using Guttman scale/Marshall Centrality Index and spatial analysis tools using ArcmapGIS 10.3.1 software, to obtain a map of the regional service center. Central Maluku Regency is an archipelago, having district clusters spread over Seram Island, Ambon, Lease Islands and Banda. The district cluster is divided into 4 regions with the highest level of regional service being in Amahei District (11.14) and the lowest in Nusa Laut (2.50). Economic growth in sub-districts in the archipelago experienced a positive trend, concentrated on Ambon Island and Banda Islands, while the Lease Islands centrality index was in the lower middle category.
\end{abstract}

Keywords: centrality index, economic dynamics, islands

\section{PENDAHULUAN}

Kawasan kepulauan dicirikan dengan kumpulan pulau-pulau besar maupun kecil dan saling berinteraksi secara ekologi, sosial, ekonomi, dan budaya, bersinergi positif untuk meningkatkan skala ekonomi dalam kawasan kepulauan tersebut. Keteresdiaan sarana, pra- 
sarana, dan fasilitas layanan di wilayah kepulauan merupakan modal dasar pertumbuhan dan perkembangan wilayah (Marasabessy 2018).

Kabupaten Maluku Tengah merupakan kabupaten tertua di Provinsi Maluku, luas wilayah seluruhnya sekitar $275.907 \mathrm{~km}^{2}$, terdiri dari luas laut $264311.43 \mathrm{~km}^{2}$ dan luas daratan 11.595 .57 $\mathrm{km}^{2}$. Pulau-pulau yang berada di Kabupaten Maluku Tengah berjumlah 49 pulau, dengan rincian pulau yang berpenduduk sebanyak 14 pulau sedangkan 35 pulau lainnya belum berpenduduk (Marasabessy et al. 2018; Dinas Kelautan dan Perikanan Provinsi Maluku 2019). Wiilayah Kabupaten Maluku Tengah memiliki keunikan jika dibandingkan dengan wilayah kabupaten lain di Maluku maupun di Indonesia. Secara admistratif pembagian wilayah kecamatan berada pada 4 kawasan kepulauan yaitu; 1) Pulau Seram memiliki luas wilayah 10.680.570 km²; 2) Pulau Ambon dengan luas $384.105 \mathrm{~km}^{2}$; 3) Kepulauan Lease luas wilayah $359.121 \mathrm{~km}^{2}$; dan 4) Kepulauan Banda luas wilayah $172.113 \mathrm{~km}^{2}$ (BPS Maluku Tengah 2019).

Pembangunan suatu wilayah memerlukan startegi perencanaan dan kebijakan program yang tepat. Selain itu ditentukan oleh peran serta aktif masyarakat dalam mendukung berbagai program yang dilaksanakan oleh pemerintah (Bahasoan et al. 2019). Keunikan letak geografis kecamatan di Kabupaten Maluku Tengah, didukung potensi sumber daya alam yang besar dan karakteristik sosial, budaya juga ekonomi masyarakat, cenderung memengaruhi status perkembangan suatu wilayah. Hal ini menjadi dasar pengabdian kepada masyarakat dilakukan. Tujuannya kegiatan pengabdian ini adalah dapat mengetahui tingkat sentralitas layanan masyarakat yang memadai dan pertumbuhan ekonomi berdasarkan klaster wilayah kecamatan di Kabupaten Maluku Tengah, harapannya dapat menjadi dasar kebijakan dalam penentuan pengembangan wilayah secara berkelanjutan.

\section{METODE PELAKSANAAN KEGIATAN}

Pengabdian kepada masyarakat dilakukan bersama PT. Bank Pembangunan Daerah Maluku dan Maluku Utara cabang Maluku Tengah selama tahun 2018, pada pusat wilayah kecamatan di Kabupaten Maluku Tengah. Geografis Kabupaten Maluku Tengah berbatasan bagian timur dengan Kabupaten Seram Bagian TImur (SBT), bagian barat dengan Kabupaten Seram Bagian Barat (SBB), utara dengan Laut Seram, dan selatan dengan Laut Banda. Lokasi kegiatan pengabdian terlihat pada Gambar 1 .

Pengumpulan data kajian dilakukan melalui pendekatan survei cepat (rapid survey method) secara bertahap, melalui observasi, pada saat melakukan kunjungan langsung ke lokasi kajian,

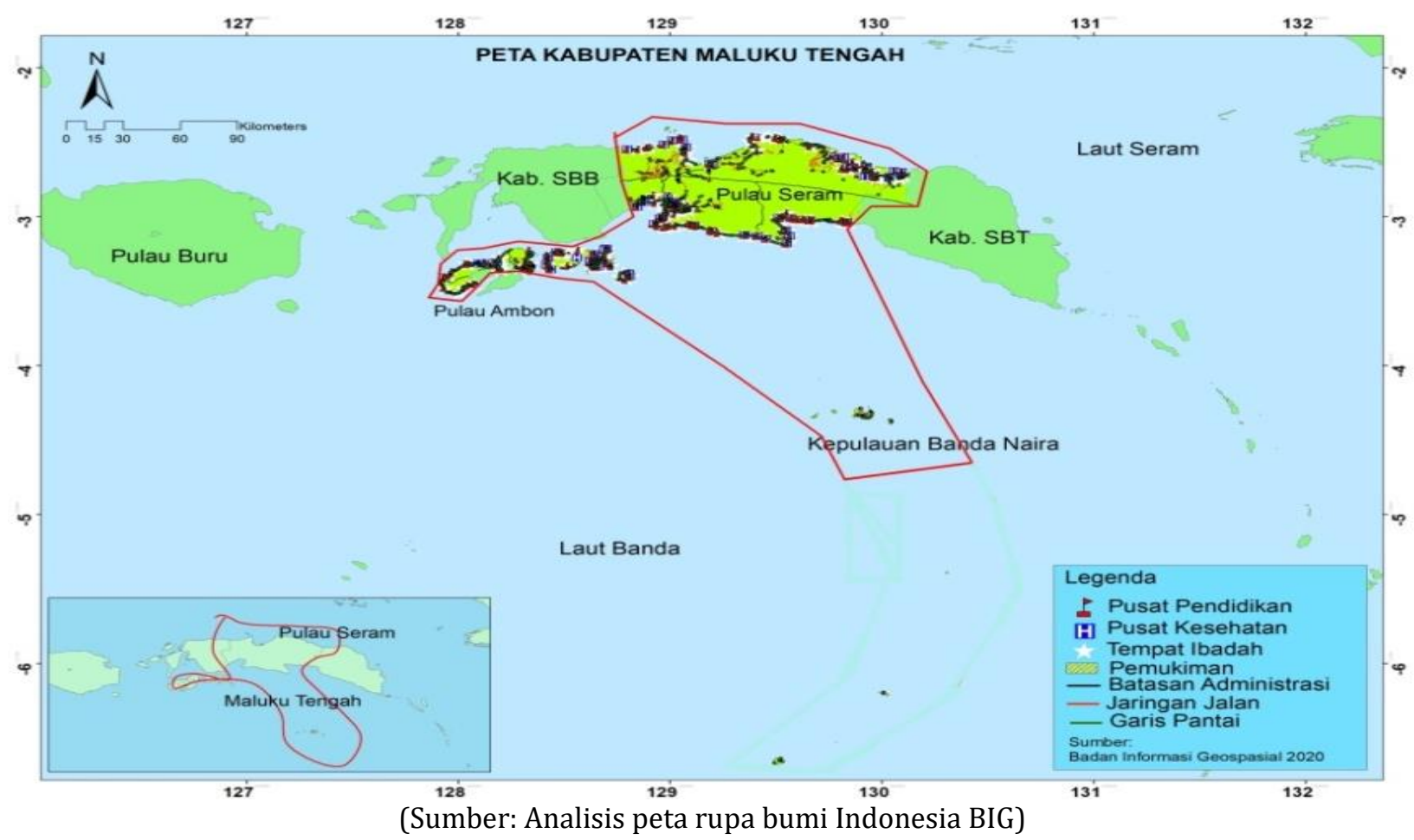

Gambar 1 Lokasi kegiatan. 
untuk mengetahui kondisi real dan struktur sosial masyarakat, diskusi (wawancara terbatas) dengan tokoh masyarakat, adat, pemuda, dan pengusaha lokal untuk mendapatkan informasi dinamika dan status sosial ekonomi. Observasi merupakan teknik megumpulkan data dengan melihat keadaan realita lingkungan yang dikaji (Kartika et al. 2017).

Konektivitas ekonomi masyarakat pesisir dan kepulauan terkait pusat pelayanan wilayah menjadi fokus kajian. Metode kuntitatif digunakan dalam menghimpun data potensi, sarana, prasarana, dan fasilitas pendukung suatu wilayah meliputi 5 aspek dan 14 asset fasilitas seperti; 1) Aspek pendidikan (SD/MAD-IB, SMP/MAD-SAN, SMA/SMK/MAD-ALIAH, dan Perguruan Tinggi); 2) Aspek kesehatan (rumah sakit, puskesmas dan puskesmas pembantu); 3) Aspek religious/ agama (masjid, gereja, dan pura); 4) Aspek industri (perseroan terbatas/private sector dan industri pariwisata/perhotelan); dan 5) Aspek perdagangan (pasar tradisional dan pasar moderen/mini market), dukungan data lain diperoleh melalui studi pusataka dan data statistik wilayah dari BPS Kabupaten Maluku Tengah. Batas wilayah geografis dan administratif diperoleh dari analisis pemetaan citra satelit menggunakan perangkat lunak ArcMapGis, peta Rupa Bumi Indonesia (RBI) dari Badan Informasi Geospasial (BIG), dan data sekunder lain dari lembaga terkait.

Metode skalogram (analisis skala Guttman/ Indeks Sentralitas Marshall) digunakan untuk melihat kemampuan pelayanan suatu pusat wilayah, ditinjau dari jumlah unit fasilitas yang terdapat pada pusat pelayanan. Nilai keterpusatan dapat diperoleh dari jumlah total bobot masing-masing jenis fasilitas dikalikan jumlah fasilitas tersebut. Prinsip pembobotan suatu fasilitas dilakukan dengan cara membagi nilai sentralitas gabungan (100) dengan jumlah fasilitas yang terdapat di seluruh pusat pelayanan. Semakin banyak dan lengkapnya fasilitas di suatu wilayah, menjadi tolak ukur perkembangan wilayah tersebut (Shara 2018). Pusat-pusat pelayanan tersebut selanjutnya dikelompokkan secara interval berdasarkan nilai sentralitas debgab persamaan berikut:

$$
\mathrm{C}=\mathrm{t} / \mathrm{T}
$$

Keterangan:

$$
\begin{array}{ll}
\mathrm{C} & =\text { Indeks sentralitas } \\
\mathrm{T} & =\text { Nilai Sentralitas Gabungan } \\
\mathrm{T} & =\text { Jumlah total asset fasilitas/atribut } \\
& \text { dalam sistem }
\end{array}
$$

Perhitungan koeffisien reproduktifitas/coeffisien of reproducibility (COR) perlu dilakukan untuk mengetahui analisis skalogram layak digunakan, jika memiliki nilai 0,9-1 menunjukan bahwa indeks sentralitas/pusat pemukiman pada suatu wilayah memiliki pengaruh yang nyata. Persamaan yang digunakan adalah sebagai berikut:

$$
\mathrm{COR}=1-\frac{\sum e}{N \times K}
$$

Keterangan

$\mathrm{COR}=$ Koofisien reproduksi

$\mathrm{E}=$ Jumlah kesalahan/error

$\mathrm{N}=$ = Jumlah subjek/ wilayah yang diteliti

$\mathrm{K}=$ = Jumlah objek fasilitas yang diteliti

Penentuan kategori hirarki pembagian pusat wilayah interaksi yang memiliki pengaruh paling tinggi, maka dilakukan penentuan range/jangkauan ketersediaan fasilitas pada masing-masing wilayah. Namun sebelumnya perlu membuat interval kelas yang akan menentukan jumlah hirarki wilayah, melalui perbandingan antara range dengan jumlah orde yang telah ditentukan, analisis ini menggunakan modifikasi persamaan yang digunakan (Gaffara et al. 2017) sebagai berikut

$$
\mathrm{R}=\mathrm{Jf}(1)-\mathrm{Jf}(0)
$$

Interval kelas $=\mathrm{R} / 0$

Keterangan:

$\mathrm{R} \quad=$ Range $/$ jangkauan

Jf (1) = Jumlah fasilitas terbanyak

Jf $(0)=$ Jumlah fasilitas terbatas

$0=$ = Jumlah orde yang ditentukan (umumnya 4)

\section{HASIL DAN PEMBAHASAN}

\section{Karakteristik Wilayah dan Fasilitas Pendukung Layanan Masyarakat pada Setiap Kecamatan di Kabupaten Maluku Tengah}

Pusat kota Kabupaten Maluku Tengah berada di Masohi Pulau Seram, sebagian wilayah administratif lain berada di Pulau Ambon berbatasan langsung dengan wilayah administratif Kota Ambon dan sebagian lagi tersebar di beberapa wilayah kepulauan seperti Kepulauan Lease (1, 2, dan 3) dan Kepulauan Banda (BPS Maluku Tengah 2019). Gugusan wilayah kepulauan Maluku Tengah merupakan kumpulan pulau besar dan kecil yang secara fungsional berinteraksi dari sisi ekologis, ekonomi, sosial, dan budaya, baik secara individu maupun secara sinergis dapat meningkatkan skala ekonomi di 
sekitar kawasan pulau tersebut (Marasabessy 2018).

Berdasarkan analisis skalogram dan hasil tabulasi data dari Badan Pusat Statistik Kabupaten Maluku Tengah tahun 2018, terkait sebaran sarana, prasarana, dan fasilitas pendukung layanan wilayah pada masing-masing kecamatan, didapatkan error (kesalahan) sebesar 12 dengan jumlah total fasilitas yang ada sebesar 1568. Dengan demikian setelah dilakukan perhitungan COR (coeffisien of reproducibility) dengan rumus yang ada didapatkan COR sebesar 0,99, hal ini menjelaskan bahwa analisis skalogram terhadap pusat layanan masyarakat pada setiap kecamatan di Kabupaten Maluku Tengah dianggap layak. Sebaran jumlah sarana, prasarana, dan fasilitas pendukung pusat wilayah terdapat pada (Gambar 2).

\section{Indeks Sentralitas Kecamatan di Kabupaten Maluku Tengah}

Penentuan pusat layanan wilayah (hirarki) pada kecamatan di Kabupaten Maluku Tengah disusun berdasarkan jumlah fasilitas pada setiap kecamatan dengan membuat interval kelas. Penentuan range/jangkauan diperoleh dengan membuat selisih perhitungan jumlah fasilitas terbanyak dengan jumlah fasilitas terbatas. Hasil perhitungan itu diperoleh jumlah range fasilitas ialah 7, sedangkan interval kelas sebanyak 5 . Hasil pengamatan di lapangan dan penyesusian data BPS Kabupaten Maluku Tengah tahun 2018, diketahui dari 14 asset fasilitas yang di input seperti; (SD/MAD-IB, SMP/MAD-SAN, SMA/ SMK/MAD-ALIAH; perguruan tinggi; rumah sakit, puskesmas; puskesmas pembantu; masjid, gereja; pura; perseroan terbatas/private sector; pariwisata/perhotelan; pasar tradisional dan pasar modern/mini market), diketahui Kecamatan Kota Masohi memiliki sebaran asset fasilitas paling lengkap sebanyak 14 dan fasilitas terbatas berjumlah 7 terdapat di Kecamatan Telutih, TNS, Saparua Timur, dan Nusa Laut. Lebih jelas kategori hirarki pusat wilayah pada masing-masing kecamatan dapat di lihat pada (Tabel 1).

Kecamatan Salahutu menempati posisi 2 dengan jumlah asset fasilitas sebanyak 13 . Berada di kawasan Pulau Ambon menjadi salah satu faktor penunjang kelengkapan fasilitas pendukung layanan masyarakat. Sedangkan Kecamatan Amahei memiliki total asset faslitas sebanyak 9. Berdasarkan (Tabel 1) diketahui, total pusat layanan di Kabupaten Maluku Tengah terbagi dalam 5 hirarki tersebar pada 18 kecamatan dengan jarak interval kelas antar kategori sebesar 2 orde. Dengan demikian kelompok kecamatan dengan indeks sentralitas sangat tinggi memiliki interval kelas 10-11 orde, dan sangat rendah memiliki interval kelas 2-3 orde. Agar dapat memahami lebih jelas pusat layanan masyarakat (sentralitas) yang tersebar di setiap kecamatan Kabupaten Maluku Tengah, maka dilakukan klasterisasi berdasarkan letak geografis, yaitu kelompok kecamatan yang ada di Pulau Seram dan Ambon, Kepulauan Lease dan Banda.

\section{Sentralitas Kecamatan di Pulau Seram}

Berdasarkan empat pembagian wilayah administratif kecamatan di Kabupaten Maluku Tengah, diketahui jumlah sebaran kecamatan terpusat di Pulau Seram, yakni sebanyak 10 kecamatan meliputi: Kecamatan Tehoru, Telutih, Amahei, Kota Masohi, Teluk Elpaputih, Teon Nila Serua (TNS), Seram Utara, Seram Utara Barat,

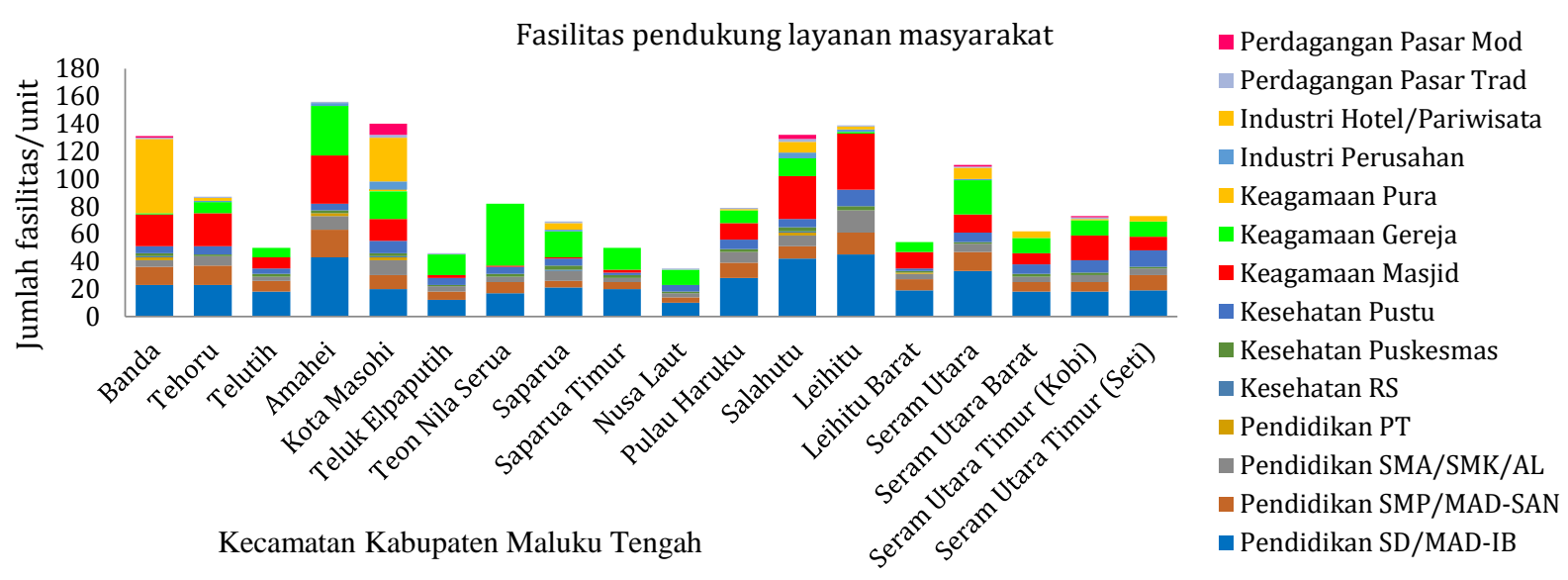

(Sumber: Analisis skalogram dan data BPS Kabupaten Maluku Tengah Tahun 2018)

Gambar 2 Sebaran fasilitas pendukung layanan masyarakat pada masing-masing kecamatan. 
Tabel 1 Indeks sentralitas kecamatan di Maluku Tengah

\begin{tabular}{lcccc}
\hline \multicolumn{1}{c}{ Lokasi Kecamatan } & Input atribut gabungan & Indeks sentralitas & Kategori hirarki & Orde \\
\hline Banda Naira & 131 & 9,35 & II & $8-9$ \\
Tehoru & 87 & 6,21 & III & $6-7$ \\
Telutih & 50 & 3,57 & IV & $4-5$ \\
Amahei & 156 & 11,14 & I & $10-11$ \\
Kota Masohi & 140 & 10,00 & I & $10-11$ \\
Teluk Elpaputih & 46 & 3,28 & V & $2-3$ \\
Teon Nila Serua (TNS) & 82 & 5,85 & III & $6-7$ \\
Saparua & 69 & 4,92 & III & $6-7$ \\
Saparua Timur & 50 & 3,57 & IV & $4-5$ \\
Nusa Laut & 35 & 2,50 & V & $2-3$ \\
Pulau Haruku & 79 & 5,64 & III & $6-7$ \\
Salahutu & 132 & 9,42 & II & $8-9$ \\
Leihitu & 139 & 9,92 & I & $10-11$ \\
Leihitu Barat & 54 & 3,85 & IV & $4-5$ \\
Seram Utara & 110 & 7,85 & II & $8-9$ \\
Seram Utara Barat & 62 & 4,42 & IV & $4-5$ \\
Seram Utara Timur (Kobi) & 73 & 5,21 & IV & $4-5$ \\
Seram Utara Timur (Seti) & 73 & 5,21 & IV & $4-5$ \\
\hline
\end{tabular}

Sumber: Analisis data primer dan BPS Kabupaten Maluku Tengah 2018

Seram Utara Timur (Kobi), dan Seram Utara Timur (Seti) (BPS Kabupaten Maluku Tengah 2018). Secara geografis sebagian besar wilayah kecamatan berada pada kawasan pesisir dan beberapa memiliki wilayah pulau kecil, dari 10 kecamatan hanya 1 kecamatan yang memiliki dominansi wilayah continental/daratan, yaitu Kecamatan Teon Nila Serua (TNS), walaupun memiliki batasan wilayah perairan namun luas kawasan pesisir relatif kecil dan aktivitas masyarakat lebih terpusat pada wilayah daratan. Gambar 3 menunjukkan indeks sentralitas wilayah kecamatan di Pulau Seram.

Berdasarkan Gambar 3, diketahui indeks sentralitas terbesar berada pada Kecamatan Amahei, yaitu sebesar 11,14 termasuk kategori hirarki I dan terendah di Kecamatan Teluk Elpaputih sebesar 3,28 berada pada hirarki V. Tingginya indeks sentralitas di Kecamatan Ahamei, dipengaruhi oleh populasi penduduk yang tinggi sebesar 49.449 jiwa, selain itu Kecamatan Amahei memiliki luas wilayah yang besar, yaitu sekitar $161.907 \mathrm{~km}^{2}$, merupakan kecamatan dengan jarak terdekat dengan kota kabupaten dan memiliki dukungan fasilitas aktivitas masyarakat yang relatif lengkap. Jumlah fasilitas pendidikan sebanyak 75 unit terdiri dari SD/MAD-IB, SMP/MAD-SAN, SMA/SMK/MADALIAH dan perguruan tinggi, fasilitas kesehatan sebanyak 7 unit seperti puskemas dan puskesmas pembantu, fasilitas keagamaan memiliki 71 tempat ibadah (masjid dan gereja), fasilitas industri dan perdagangan tersedia dan berkembang dinamis.
Berdasarkan informasi yang diperoleh dari diskusi dengan perwakilan warga masyarakat (negeri/desa) di wilayah Kecamatan Amahei diketahui bahwa, dinamika sosial ekonomi di kawasan ini cenderung berkembang ke arah positif, hal ini tidak lepas dari ketersediaan potensi sumber daya alam yang besar, baik di wilayah perairan maupun di daratan. Kondisi ini terlihat pada saat pengamatan dan survei lokasi diperoleh pertumbuhan ekonomi tidak hanya terjadi pada sektor formal, namun ada trend pertumbuhan ekonomi di sektor informal khususnya nelayan dan petani kebun. Sentra penangkapan dan pengumpul ikan (plasma perikanan) dan hasil kebun berkembang baik, distribusi produk dapat berlangsung setiap minggu pada daerah tujuan seperti Kota Masohi dan wilayah kecamatan penyangga di Pulau Ambon seperti; Kecamatan Salahutu dan Kota Ambon.

Kondisi ini berdampak secara luas pada pertumbuahan ekonomi lokal, terbukti distribuasi barang dan jasa pada pengusaha lokal mengalami peningkatan yang baik. Input pertumbuhan ekonomi yang teridentifikasi di Kecamatan Amahei tidak lepas dari letak geografis dan demografi wilayah dimana pemukiman masyarakat dominan ada di kawasan pesisir, wilayah cenderung terkoneksi secara langsung dengan pusat Kota Kabupaten Maluku Tengah (Masohi). Aksesibilitas lebih mudah dan cepat melalui jalur laut dengan wilayah pusat Kota Provinsi Maluku (Ambon). Dukungan fasilitas pelabuhan kapal penyeberangan rakyat dan jasa 


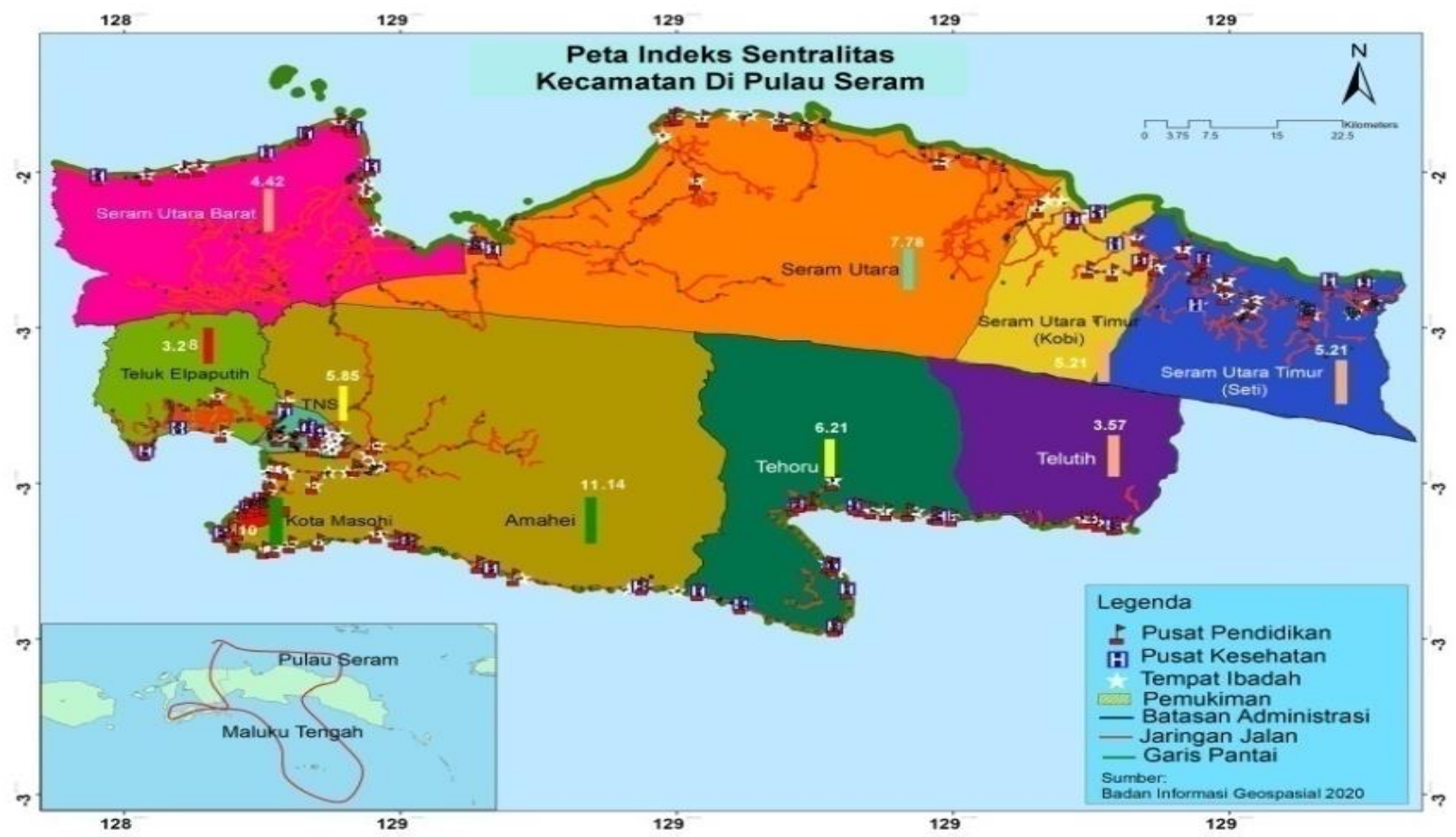

(Sumber: Analisis Spasial Peta Rupa Bumi Indonesia BIG)

Gambar 3 Indeks sentralitas wilayah kecamatan di Pulau Seram.

angkutan laut yang memadai, menjadi lokasi transit utama bagi pengunjung yang akan melanjutkan perjalanan ke beberapa wilayah lain di Kabupaten Maluku Tengah bahkan di wilayah kabupaten lain di Pulau Seram. Hal ini turut memberikan input positif terhadap partumbuhan ekonomi di kawasan tersebut. Menurut (Saka 2017), bonus demografi digerakkan oleh struktur masyarakat dan dipengaruhi oleh aspek pendidikan, kesehatan, kebijakan perekonomian, dan dukungan pemerintah.

Rendahnya indeks sentralitas di Kecamatan Teluk Elpaputih, disebabkan kurangnya fasilitas pendudukung aktivitas masyarakat seperti; pendidikan, kesehatan, keagamaan, industry, dan perdagangan. Selain itu, populasi penduduk kecil sebesar 9.330 jiwa dengan luas wilayah 12.000 $\mathrm{km}^{2}$. Interaksi masyarakat Kecamatan Teluk Elpaputih dilakukan secara terbatas untuk memenuhi kebutuhan hidup keseharian, konektivitas ke pusat wilayah kecamatan relativ rendah, dilakukan pada waktu-waktu tertentu dalam kunjungan kekerabatan. Kebutuhan sandang dan pangan diperoleh secara personal dari kegiatan berkebun dan nelayan tradisional. Masyarakat dalam memenuhi kebutuhan kesehatan dan hiburan umumnya dilakukan dengan berkunjung secara langsung ke pusat kota kabupaten. Tidak ditemui fasilitas industri (private sector maupun pariwisata), untuk fasilitas perdagangan (pasar tradisonal) dalam proses pembangunan dan diprediksi selesai pada tahun 2020, sedangkan pasar moderen (mini market) sama sekali tidak tersedia. Menurut (Shara 2018), sentralitas wilayah identik secara spasial menggambarkan konektivitas geografis, berdasarkan kemudahan akses, informasi, asset fasilitas dan sarana prasarana pendukung aktivitas masyarakat. Wilayah yang memiliki nilai sentralitas tinggi menjadi pusat orientasi kegiatan dan wilayah tujuan (destination).

\section{Sentralitas Kecamatan di Pulau Ambon}

Pembagian wilayah kecamatan di Kabupaten Maluku Tengah yang tersebar di Pulau Ambon meliputi tiga kecamatan, yaitu Kecamatan Salahutu, Leihitu, dan Leihitu Barat dengan luas ketiga wilayah sebesar $38.410 \quad \mathrm{~km}^{2}$ (BPS Kabupaten Maluku Tengah 2018). Berdasarkan analisis skalogram diperoleh indeks sentralitas tertinggi berada pada Kecamatan Leihitu dengan nilai sebesar 9,92 termasuk dalam kategori hirarki I, dan terendah di Kecamatan Leihitu Barat dengan indeks sentralitas 3,85, berada pada hirarki IV. Sedangkan Kecamatan Salahutu memiliki indeks sentralitas 9,42 berada pada hirarki II. Sebaran indeks sentralitas pada kecamatan dalam wilayah administrasi Kabupaten Maluku Tengah di Pulau Ambon dapat dilihat pada (Gambar 4).

Jumlah populasi penduduk yang tinggi sebesar 55.027 jiwa jika dibandingkan populasi 


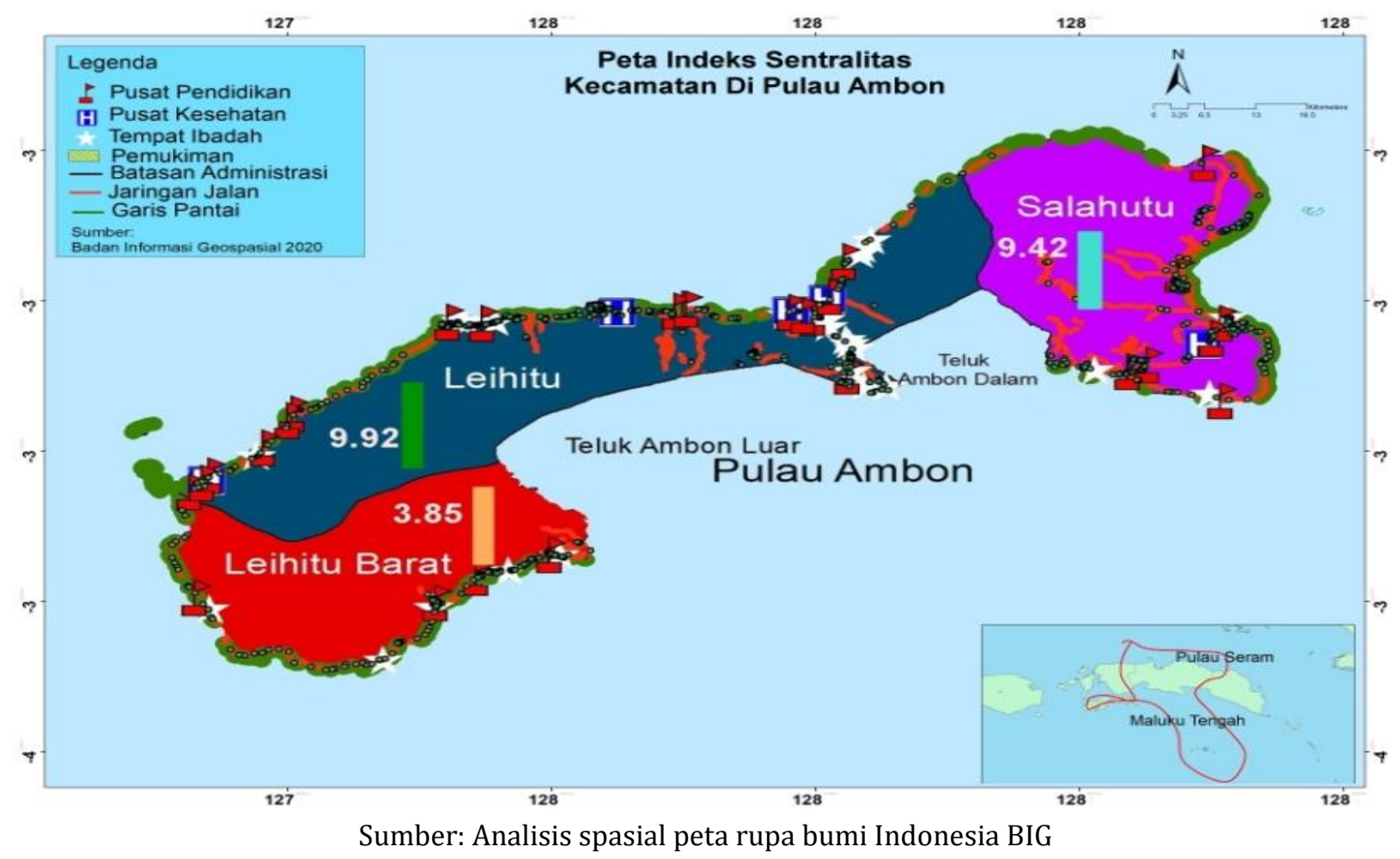

Gambar 4 Indeks sentralitas wilayah kecamatan di Pulau Ambon.

penduduk pada wilayah kecamatan lain di Kabupaten Maluku Tengah, menjadi salah satu indikator penentu tingginya indeks sentralitas di Kecamatan Leihitu. Selain itu, sebaran fasilitas pendukung aktivitas masyarakat yang memadai merupakan indikator lain dalam menentukan pusat pertumbuhan wilayah. Berdasarkan komparasi data BPS kabupaten Maluku Tengah dan survei lapangan yang dihimpun selama tahun 2018 diperoleh jumlah fasilitas pendidikan merupakan asset paling banyak terdiri dari (SD/MAD-IB, SMP/MAD-SAN, SMA/SMK/MADALIAH sebanyak 77 unit, fasilitas kesehatan seperti puskemas dan puskesmas pembantu berjumlah 15 unit dan fasilitas tempat ibadah sebanyak 46 unit. Fasilitas lain seperti, industri dan perdagangan relatif terbatas.

Historical culture Kecamatan Leihitu yang panjang, melekat erat dengan statusnya sebagai negeri adat dan letak geografis di wilayah pesisir, memilki peran yang cukup signifikan dalam perkembangan wilayah Maluku Tengah dan sekaligus berpengaruh pada perkembangan wilayah Provinsi Maluku. Letaknya yang strategis pada Pulau Ambon tidak dipungkiri turut berkontribusi secara politik sosial dan ekonomi. Distribusi barang dan jasa seperti produk perikanan, perkebunan, hutan, dan jasa ekosistem (wisata bahari) merupakan daya tarik kuat Kecamatan Laihitu.
Sebagai kecamatan yang baru dimekarkan pada tahun 2013, Kecamatan Leihitu Barat masih relatif muda, sehingga asset fasilitas pendukung wilayah masih terbatas (Rahman \& Suriani 2016). Faslitas pendukung aktivitas masyarakat seperti pendidikan sebanyak 32 unit, kesehatan puskesmas dan puskemas pembantu berjumlah 3 unit, tempat ibadah 19 unit, sedangkan fasilitas indsutri dan perdagangan relatif sangat terbatas. Jumlah fasilitas terbangun yang telah ada saat ini, sejatinya merupakan warisan fasilitas dari wilayah administratif kecamatan sebelumnya. Faktor lain adalah rendahnya populasi penduduk, yaitu sebanyak 20.536 jiwa, dari data (BPS Kabupaten Maluku Tengah 2018), diketahui jumlah penduduk relatif lebih rendah jika dibandingkan dengan dua kecamatan lain di Pulau Ambon, yaitu Kecamatan Salahutu dan Leihitu.

Kecamatan Salahutu melengkapi daftar wilayah administratif kecamatan di Kabupaten Maluku Tengah yang berada di Pulau Ambon. Agak berbeda dengan dua wilayah kecamatan lain, Salahutu merupakan wilayah kecamatan yang menempati urutan kedua dalam daftar jumlah total fasilitas yang diinput dalam kajian pengabdian kepada masyarakat di Kabupaten Maluku Tengah. Kecamatan Salahutu memiliki 13 fasilitas dari 14 total fasilitas pendukung seperti; fasilitas pendidikan (SD/MAD-IB, SMP/MADSAN, SMA/SMK/MAD-ALIAH, dan perguruan 
tinggi) sebanyak 61 unit, fasilitas kesehatan 10 unit terdiri dari rumah sakit, puskesma dan puskemas pembantu, keagamaan/tempat ibadah sebanyak 44 unit terdiri dari (masjid dan gereja), fasilitas industri sebanyak 12 unit dan fasilitas perdagangan/pasar 5 unit. Faktor yang membedakan kelengkapan jumlah asset ialah pada Kecamatan Salahutu tidak terdapat fasilitas tempat ibadah (Pura). Fasilitas asset pendukung lain seluruhnya tersedia, hanya berbeda jumlah masing-masing fasilitas.

Letak geografis wilayah Kabupaten Maluku Tengah yang terpisah pada beberapa wilayah adminstratif, memberikan keunikan khusus terhadap interaksi, orientasi, dan destinasi masyarakat dalam wilayah Kabupaten Maluku Tengah. Kondisi ini menciptakan konektivitas wilayah berdasarkan fungsi peruntukan interaksi masyarakat di lokasi setempat. Masyarakat Maluku Tengah yang menempati wilayah administratif kecamatan di Pulau Ambon, jika berinteraksi secara sosial dan ekonomi lebih cenderung memilih wilayah dalam batas administratif Kota Ambon, dibandingkan harus berinteraksi secara langsung dengan ibukota Kabupaten Masohi di Pulau Seram. Sebagai kabupaten kepulauan yang dipisahkan oleh lautan, masyarakat Maluku Tengah di Pulau Ambon akan mengalami kendala dalam melakukan proses distribusi barang dan jasa jika harus menjadikan Kota Masohi sebagai lokasi sentra pemasaran.

Biaya transportasi yang tinggi, jarak yang jauh juga waktu tempuh yang lama menjadi faktor rendahnya interaksi masyarakat di kawasan ini. Mereka cenderung memilih wilayah administratif di Kota Ambon untuk melakukan kegiatan interaksi sosial seperti hubungan kekerabatan, pekerjaan, hiburan maupun sistem sosial kelembagaan, sedangkan interaksi ekonomi terjadi melalui mekanisme perdagangan jual beli. Mustakim et al. 2017 menyatakan aksesibilitas dan konektivitas wilayah kepulauan di timur Indonesia menjadi salah satu indikator peningkatan ekonomi dan kesejahteraan masyarakat lokal. Berdasarkan hasil survei dan diskusi dengan beberapa lapisan masyarakat di tiga kecamatan tersebut, diketahui bahwa umumnya mereka membawa hasil produksi perikanan, peternakan, perkebunan, dan hutan ke Kota Ambon untuk diperjualbelikan, hal ini karena letak Kota Ambon memiliki jarak yang lebih dekat dan merupakan barometer pertumbuhan ekonomi di Provinsi Maluku. Sedangkan interaksi masyarakat dengan pusat wilayah kabupaten dilakukan jika berkaitan secara politik dan aktivitas pemerintahan.

Prospek pertumbuhan ekonomi di kawasan ini relatif lebih baik jika dibandingkan dengan kecamatan lain di Pulau Seram. Indikator itu terlihat dengan tingginya distribuasi hasil produk perikanan, perkebunan, dan pariwisata. Bahasoan et al. 2019 menjelaskan pertumbuhan ekonomi suatu wilayah menjadi indikator kesejahteraan masyarakat, jika terjadi peningkatan, diharapkan pertumbuhan tersebut dapat dinikmati secara merata oleh seluruh masyarakat. Tidak dipungkiri tiga kecamatan di Pulau Ambon menjadi sentra produksi/suplai bahan baku khususnya dari sektor perikanan dan perkebunan. Sebagian besar negeri/desa di tiga kecamatan ini merupakan wilayah pesisir dengan potensi perikanan dan kelautan yang besar. Sebagian besar produksi perikanan di wilayah Kota Ambon bersumber dari wilayah Kecamatan Salahutu, Leihitu, dan Leihitu Barat. Selain itu, industri pariwisata bahari menjadi daya tarik minat khusus bagi wisatawan lokal, nusantara maupun mancanegara yang berkunjung ke Pulau Ambon. Walaupun secara administratif ketiga wilayah kecamatan ini masuk Kabupaten Maluku Tengah, namun konektivitas wilayah dengan Kota Ambon memiliki intensitas yang lebih tinggi. Menurut Hakim et al. 2018 konektivitas transportasi merupakan asset penting dalam membantu interaksi intra dan antar wilayah. Peningkatan intra wilayah ditujukan untuk meningkatkan kemudahan hubungan antar wilayah, terutama untuk membuka aksesibilitas dengan wilayah terisolasi (hinterland).

\section{Sentralitas Kecamatan di Kepulauan Lease}

Wilayah administrasi kecamatan lainnya di Kabupaten Maluku Tengah adalah Kepulauan Lease yang terdiri dari Pulau Haruku, Saparua, Nusa Laut. Wilayah ini tersusun atas tiga pulau kecil berserta beberapa gugusan pulau sangat kecil yang lain. Memiliki total luas wilayah $359.121 \mathrm{~km}^{2}$ terbagi dalam empat kecamatan, yaitu Kecamatan Pulau Haruku, Saparua, Saparua Timur dan Nusa Laut (BPS Kabupaten Maluku Tengah 2018). Hasil analisis skalogram diketahui indeks sentralitas tertinggi berada pada Kecamatan Pulau Haruku dengan nilai sebesar 5,64 berada pada kategori hirarki III, dan terendah di Kecamatan Nusa Laut memiliki indeks sentralitas 2,50, tergolong hirarki V. Sedangkan Kecamatan Saparua dan Saparua Timur masing-masing memiliki indeks sentralitas sebesar 4,92 dan 3,57 . Sebaran indeks sentralitas pada kecamatan 
dalam wilayah administrasi Kabupaten Maluku Tengah di Kepulauan Lease dapat dilihat pada (Gambar 5).

Berdasarkan Gambar 5, diketahui wilayah kecamatan di Kabupaten Maluku Tengah dalam kawasan Kepulauan Lease berada pada kategori hirarki menengah ke bawah. Di mana pusat pertumbuhan wilayah lebih besar berada di Kecamatan Pulau Haruku (Pelauw). Tingginya indeks sentralitas di wilayah ini cenderung dipengaruhi oleh tingginya populasi penduduk, yaitu sebesar 28.012 jiwa, memiliki kelengkapan fasilitas pendukung aktivitas masyarakat seperti fasilitas pendidikan sebanyak 47 unit terdiri dari SD/MAD-IB, SMP/MAD-SAN dan SMA/SMK/ MAD-ALIAH, fasilitas kesehatan seperti puskesmas dan puskesmas pembantu berjumlah 9 unit, tempat ibadah sebanyak 21 unit terdiri dari masjid dan gereja, sedangkan fasilitas industri dan perdangan masih sangat terbatas.

Nusa Laut merupakan wilayah kecamatan dengan indeks sentralitas paling rendah, kondisi ini dilatar belakangi oleh karakteristiknya sebagai pulau kecil dan memiliki daya dukung wilayah yang terbatas. Faktor lain adalah terbatasnya jumlah fasilitas pendukung aktivitas masyarakat seperti pendidikan, kesehatan, keagamaan, industry, dan perdagangan. Selain itu, faktor homogenitas struktur sosial di Kecamatan Nusa Laut menjadi salah satu penyebab terbatasnya pembangunan fasilitas pendukung lain. Menurut Yaroseray 2018, homogenitas dalam masyarakat merupakan kesamaan nilai dalam membentuk sebuah tatanan masyarakat lokal/desa, pada umunya memiliki kesamaan kepentingan dan mampu membentuk sebuah pola tata ruang desanya. Peningkatan sarana dan prasarana masyarakat merupakan bagian yang terinegrasi dengan layanan publik, hal ini mampu menjamin kesejahteraan masyarakat (Hakim 2017).

Pertumbuhan ekonomi di kawasan Kepulauan Lease mengalami trand peningkatan yang positif. Karakteristik masyarakat di wilayah Kepulauan Lease terbentuk melalui perpaduan antara adat dan budaya lokal, sumber daya alam, letak geografis wilayah pesisir, dan pulau kecil, di mana ketiga pulau dalam gugusan Kepulauan Lease berada di antara Pulau Seram dan Ambon. Menurut Safitri 2018, pembangunan ekonomi daerah adalah proses di mana pemerintah daerah, masyarakat, dan swasta bersinergi positif mengelola sumber daya alam, menghargai kearifan lokal yang ada, dan membentuk suatu pola kemitraan. Keterbukaan terhadap informasi, menciptakan konektivitas yang positif dengan wilayah lain seperti; Pulau Seram dan Ambon. Karakteristik ini memengaruhi pola pikir masyarakat, sehingga membentuk persepsi sebagai masyarakat perantau. Indikator ini terlihat dengan banyaknya masyarakat di Kepulauan Lease menempati wilayah lain di Pulau Seram

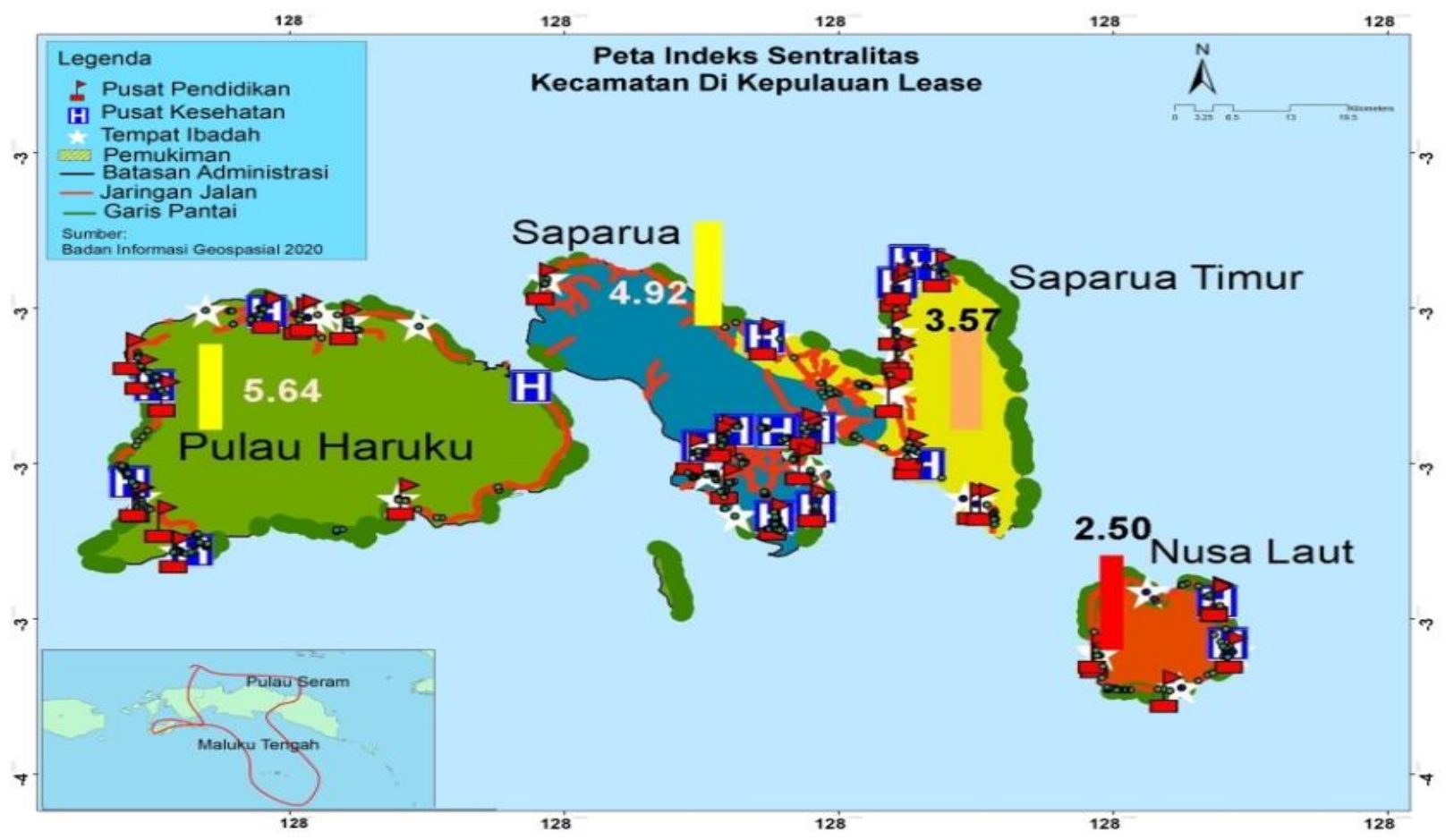

Sumber: Analisis Spasial Peta Rupa Bumi Indonesia BIG

Gambar 5 Indeks sentralitas wilayah kecamatan di Kepulauan Lease. 
dan Ambon bahkan beberapa pulau lain di luar Provinsi Maluku. Sebagian besar berprofesi sebagai pekerja di sektor formal seperti ASN, TNI, POLRI, dan sebagian lagi menjalankan profesi di sektor informal seperti nelayan, berkebun, berdagang, oprator transportasi laut tradisional, dan buruh pekerja harian.

\section{Sentralitas Kecamatan di Kepulauan Banda}

Wilayah administrasi kecamatan di Kabupaten Maluku Tengah yang memiliki wilayah geografis kepulauan dengan jarak terjauh adalah Kecamatan Banda. Letaknya di selatan Pulau Seram dan tenggara Pulau Ambon, tepatnya di sekitar perairan Laut Banda. Memiliki luas total wilayah sebesar $172.113 \mathrm{~km}^{2}$, jarak tempuh sejauh $183.840 \mathrm{~km}$ dari pusat kota Kabupaten Maluku Tengah, jumlah pulau sebanyak 10 pulau, terdiri dari 7 pulau berpenduduk dan 3 pulau tidak penduduk (BPS Kabupaten Maluku Tengah 2018). Memiliki indeks sentralitas 9,35 menempatkan Kecamatan Banda sebagai wilayah dengan pusat layanan dalam ketegori hirarki II. Gambar 6 menunjukkan indeks sentralitas wilayah kecamatan di Kepulauan Banda.

Fenomena berbeda yang ditemui pada kawasan ini adalah letak geografis yang cenderung jauh, dan terdiri dari gugusan pulau kecil, memiliki keterbatasan daya dukung wilayah, namun jika dibandingkan dengan wilayah lain yang terintegrasi dengan pusat wilayah Ka- bupaten Maluku Tengah atau wilayah lain pada batas admnistrasi kecamatan di Pulau Ambon dan Kepulauan Lease, ternyata Kecamatan Banda memiliki indeks sentralitas yang jauh lebih tinggi. Berdasarkan klasifikasi hirarki wilayah ini termasuk dalam kategori II, yakni memiliki orde daya tarik wilayah sebesar 8-9, berada 1 tingkatan di bawah Kecamatan Amahei, Kota Masohi, dan Leihitu.

Tingginya indeks sentralitas Kecamatan Banda dipengaruhi oleh banyak fasilitas pendukung aktivitas masyarakat khususnya terkait industri pariwisata bahari. Menurut Widiansyah 2017 keberadaan industri di suatu wilayah menjadi salah satu indikator perubahan struktur sosial dan ekonomi masyarakat. Memiliki fasilitas pariwisata/hotel/penginapan sebanyak 54 unit didukung fasilitas perdagangan (pasar tradisional dan modern) yang saling terintegrasi dengan fasilitas pendidikan, kesehatan, dan agama (BPS Kabupaten Maluku Tengah 2018). Karakteristik wilayah Kepualuan Banda dikenal sejak lama sebagai salah satu wilayah yang memiliki situs sejarah peninggalan masa lalu, menjadikannya sebagai salah satu destinasi pariwisata yang potensial. Keunikan ekologi pesisir dan pulau kecil juga sejarah budaya yang melekat di kawasan Banda memberikan kontribusi besar dalam pengembangan wilayah. Pertumbuhan ekonomi mengalami trend peningkatan yang progresif. Sejak lama dikenal sebagai wilayah
129

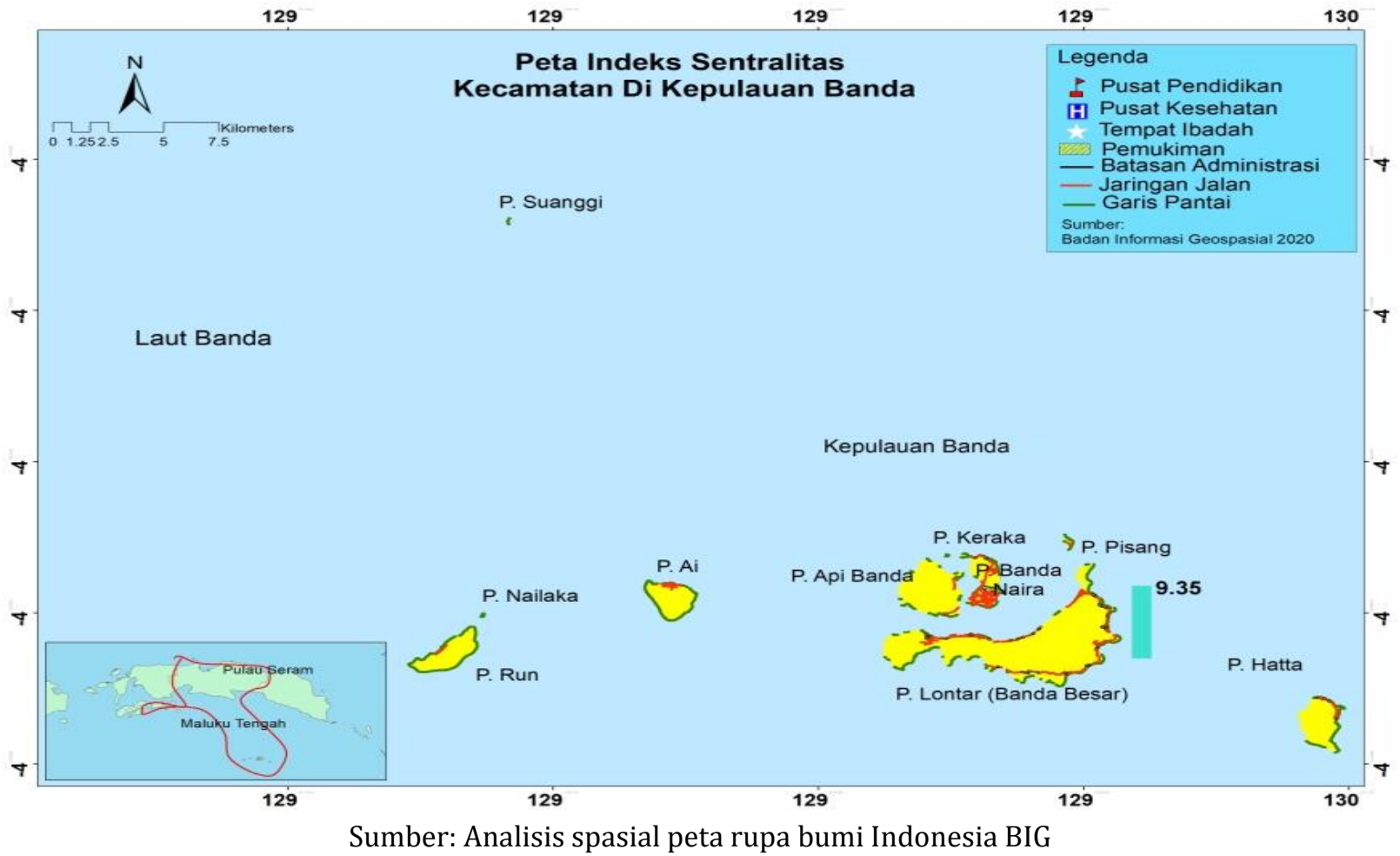

Gambar 6 Indeks sentralitas wilayah kecamatan di Kepulauan Banda. 
pengahasil rempah-rempah (cengkeh dan pala) juga menjadi salah satu sentra industri perikanan tuna di Indonesia bagian timur. Hal itu teridentifikasi dengan banyaknya armada penangkapan ikan tuna milik nelayan Banda dan beberapa kapal penampung milik swasta yang beroperasi di perairan Banda. Menurut (Ririmase 2015), sektor perikanan, industri, pertambangan, hingga pariwisata merupakan sektor terkait ekonomi bahari yang selama ini mengemuka dalam pengelolaan kawasan pesisir dan pulau kecil. Warisan budaya dan sejarah di seluruh dunia selalu dihadapkan pada modernisasi, seperti pembangunan infrastruktur, telekomunikasi, informasi, transportasi, dan hiburan (wisata) sebagai upaya untuk mendukung pembangunan ekonomi di suatu wilayah (Hosagrahar 2015; Farid 2020).

Dukungan lain adalah telah tersedianya kantor perwakilan daerah UPT dalam pengurusan administrasi kependudukan, lembaga social, dan dinas terkait. Persoalan yang sering kali dihadapi masyarakat Kepulauan Banda berkaitan dengan biaya dan keersediaan kebutuhan pokok, alat rumah tangga, dan bahan bakar minyak, sering kali mengalami hambatan pasok dan lonjakan harga. Hal ini dipengaruhi oleh letak geografis wilayah yang jauh dari pusat orientasi wilayah (kota, kabuapten, dan provinsi), sehingga penting menjadi perhatian seluruh stakeholders yang berkepentingan untuk mereduksi disparitas yang ada.

\section{SIMPULAN}

Klaster wilayah di Pulau Seram memiliki pusat layanan tertinggi pada Kecamatan Amahei $(11,14)$ dan Kota Masohi $(10,00)$, terendah Kecamatan Teluk Elpaputih $(3,28)$. Pada klaster wilayah Pulau Ambon pusat layanan tertinggi terdapat di Kecamatan Lehitu $(9,92)$ dan terendah Kecamatan Lehitu Barat $(3,85)$. Pada klaster wilayah Kepulauan Lease, pusat layanan tertinggi terdapat di Kecamatan Pulau Haruku $(5,64)$ dan Saparua $(4,92)$ sedangkan terendah di Kecamatan Nusa Laut $(2,50)$. Pada kalster wilayah Kepualaun Banda Naira, pusat layanan tertinggi berada pada Pulau Naira $(9,35)$ sebagai ibukota kecamatan. Secara umum pertumbuhan ekonomi di setiap klasterisasi kecamatan mengalami trend peningkatan dengan tingkatan yang berbeda, tergantung ketersediaan sarana, prasarana dan dukungan fasilitas dalam wilayah.

\section{UCAPAN TERIMA KASIH}

Terima kasih kami ucapkan pada PT. Bank Pembangunan Daerah Maluku dan Maluku Utara Cabang Maluku Tengah yang telah berkontribusi membantu dalam survei, observasi, dan pengambilan data lapangan. Juga kepada pemerintah Kabupaten Maluku Tengah dan perwakilan masyarakat pada setiap kecamatan mulai proses penghimpunan data hingga penulisan artikel ini selesai.

\section{DAFTAR PUSTAKA}

[BPS] Badan Pusat Statistik. 2018. Kabupaten Maluku Tengah Dalam Angka Tahun 2018. Penyediaan Data Untuk Perencanaan Pembangunan. (ID): Masohi.

[BPS] Badan Pusat Statistik. 2019. Kabupaten Maluku Tengah Dalam Angka Tahun 2019. Penyediaan Data Untuk Perencanaan Pembangunan. (ID): Masohi.

Bahasoan H, Hakim DB, Nurmalina R, Putri EIK. 2019. Typology and inequality between island clusters and development areas in Maluku Province. Jurnal Perspektif Pembiayaan dan Pembangunan Daerah. 7(2): 203-214. https://doi.org/10.22437/ppd.v7i2.7733

Dinas Kelautan dan Perikanan Kabupaten Maluku Tengah. 2019. Maluku Tengah Dalam Angka. Masohi. (ID): Dinas Kelautan dan Perikanan Kabupaten Maluku Tengah.

Dinas Kelautan dan Perikanan Peovinsi Maluku. 2016. Dokument Rencana Zonasi Wilayah Pesisir dan Pulau-Pulau Kecil (RZWP3K) Provinsi Maluku. Ambon. (ID): Dinas Kelautan dan Perikanan Provinsi Maluku.

Farid M. 2020. Pelestarian Warisan Sejarah Melalui Sinergi Antar-Stakeholder dan Digitalisasi Warisan Sebagai Model Pengembangan Pariwisata Banda Naira. KAMBOTI Jurnal Ilmu Sosial dan Humaniora. 1(1): 44-58. https://doi.org/10.51135/ kambotivol1iss1pp44-58

Gaffara GR, Fathu A, Fatih. 2017. Kajian Skalogram Guttman dan Indeks Sentralitas Marshall Untuk Penentuan Pusat-Pusat Pelayanan Wilayah (Studi Kasus: Kabupaten Simalungun, Provinsi Sumatra Utara). Dalam: Prosiding Seminar Nasional ReTII - 10 2015, 
Managemen Energi Untuk Pembangunan Berkelanjutan di Indonesia. Hal 150-153.

Hakim DH, Barkey RA, Wikantari R. 2018. Daya Tarik Dan Daya Dorong Perkembangan Wilayah Terhadap Persebaran Pemanfaatan Lahan Kota Sinjai Kabupaten Sinjai. Dalam: Prosiding Seminar Nasional Geomatika 2018. Penggunaan dan Pengembangan Produk Informasi Geospasial Mendukung Daya Saing Nasional. $384 \mathrm{hlm}$.

Hakim A. 2017. Analisis Dampak Pemekaran Daerah Ditinjau dari Aspek Percepatan Pertumbuhan Ekonomi dan Peningkatan Kualitas Pelayanan Publik (Studi Pemekaran Kabupaten Kepulauan Meranti dari Kabupaten Bengkalis). JOM Fekon. 4 (1); 843857. https://doi.org/10.24895/SNG.2018.30.977

Hosagrahar J. 2015. Urban Heritage and SustainableDevelopment in South Asia: A Plea for a Heritage-Aware Approach. In M. T. Albert (Ed.) Perception of Sustainability in Heritage Studies (pp. 113-124). Berlin (DE): De Gruyter. https://doi.org/10.1515/ 9783110415278-010

Kartika T, Afriza L, Fajri K. 2019. Pemberdayaan Masyarakat Di Desa Wisata Cibuntu Kabupaten Kuningan Provinsi Jawa Barat. Journal of Indonesian Tourism, Hospitality and Recreation. 2(1): 11-24. https://doi.org/ 10.17509/jithor.v2i1.16427

Marasabessy I. 2018. Pengelolaan Berkelanjutan Pulau Nusa Manu dan Nusa Leun di Kabupaten Maluku Tengah Provinsi Maluku. [Tesis]. Bogor (ID): Institut Pertanian Bogor. https:// doi.org/10.29244/jp2wd.2018.2.1.11-22

Marasabessy I, Fahrudin A, Imran Z, Agus SB. 2018. Strategi Pengelolaan Berkelanjutan Pesisir dan Laut Pulau Nusa Manu dan Pulau Nusa Leun di Kabupaten Maluku Tengah. Journal of Regional and Rural Development Planning. 2(1): 11-22. https://doi.org/10. 29244/jp2wd.2018.2.1.11-22
Rahman MA, Suriani W. 2016. Persepsi Masyarakat Terhadap Pelayanan Publik Pasca Pemekaran Kecamatan (Studi Diskriptif di Kecamatan Leihitu Barat Kabupaten Maluku Tengah). Jurnal Fikratuna. 8(1): 126-137.

Mustakim A, Nur HI, Agustinus H. 2017. Analisis Indeks Konektivitas dan Aksesibilitas Wilayah Kepulauan: Studi Kasus Kepulauan Maluku dan Papua. Jurnal Aplikasi Pelayaran dan Kepelabuhanan. 8(1): 59-68.

Ririmasse M. 2015. Pusaka Budaya Kawasan Pesisir: Tinjauan Arkeologis Atas Potensi di Kepulauan Maluku. Kalpataru Majalah Arkeologi. 24(2): 73-87. https://doi.org/ 10.24832/kpt.v24i2.36

Safitri E. 2018. Pertumbuhan Ekonomi Provinsi Kepulauan Riau. UTILITY: Jurnal Ilmiah Pendidikan dan Ekonomi. 2(1); 52-65. https://doi.org/10.30599/utility.v2i1.284

Saka TCV. 2016. Tantangan Ilmu-Ilmu Sosial Dalam Menghadapi Bonus Demografi Indonesia 2020-2030. Dalam: Prosiding Seminar Nasional tentang Tantangan IlmuIlmu Sosial dalam menghadapi Bonus Demografi 2020-2030. Bandar Lampung (ID): Universitas Lampung. 9 November 2016. 10 Hlm.

Shara ARID. 2018. Analisis Konektivitas Wilayah di Kota Denpasar. Media Komunikasi Geografi. 19(1): 42-50. https://doi.org/10.23887/mkg. v19i1.13811

Yaroseray MM. 2018. Struktur dan Tata Ruang Sosial Budaya Suku Bangsa Yokari Kabupaten Jayapura Provinsi Papua. Jurnal Ekologi Birokrasi. 6(3): 40-58. https://doi.org/ 10.31957/jeb.v6i3.782

Widiansyah S. 2017. Dampak Keberadaan Industri terhadap Perubahan Struktur Sosial Masyarakat (Studi Masyarakat Desa Bojong, Cikupa, Kabupaten Tangerang). Jurnal Hermeneutika. 3(2): 35-46. https:// doi.org/10.30870/hermeneutika.v3i2.3086 